IZA DP No. 7189

\title{
Living on the Edge:
}

Youth Entry, Career and Exit in Drug-Selling Gangs

Leandro Carvalho

Rodrigo R. Soares

January 2013 


\title{
Living on the Edge: Youth Entry, Career and Exit in Drug-Selling Gangs
}

\author{
Leandro Carvalho \\ RAND Corporation \\ Rodrigo R. Soares \\ Pontifical Catholic University of Rio de Janeiro \\ and IZA
}

\section{Discussion Paper No. 7189 \\ January 2013}

\author{
IZA \\ P.O. Box 7240 \\ 53072 Bonn \\ Germany \\ Phone: +49-228-3894-0 \\ Fax: +49-228-3894-180 \\ E-mail: iza@iza.org
}

Any opinions expressed here are those of the author(s) and not those of IZA. Research published in this series may include views on policy, but the institute itself takes no institutional policy positions. The IZA research network is committed to the IZA Guiding Principles of Research Integrity.

The Institute for the Study of Labor (IZA) in Bonn is a local and virtual international research center and a place of communication between science, politics and business. IZA is an independent nonprofit organization supported by Deutsche Post Foundation. The center is associated with the University of Bonn and offers a stimulating research environment through its international network, workshops and conferences, data service, project support, research visits and doctoral program. IZA engages in (i) original and internationally competitive research in all fields of labor economics, (ii) development of policy concepts, and (iii) dissemination of research results and concepts to the interested public.

IZA Discussion Papers often represent preliminary work and are circulated to encourage discussion. Citation of such a paper should account for its provisional character. A revised version may be available directly from the author. 


\section{ABSTRACT}

\section{Living on the Edge: Youth Entry, Career and Exit in Drug-Selling Gangs*}

We use data from a unique survey of members of drug-trafficking gangs in favelas (slums) of Rio de Janeiro, Brazil, to characterize drug-trafficking jobs and study the selection into gangs, analyzing what distinguishes gang-members from other youth living in favelas. We also estimate wage regressions for gang-members and examine their career path: age at entry, progression within the gangs' hierarchy, and short- to medium-term outcomes. Individuals from lower socioeconomic background and with no religious affiliation have higher probability of joining a gang, while those with problems at school and early use of drugs join the gang at younger ages. Wages within the gang do not depend on education, but are increasing with experience and involvement in gang-related violence. The two-year mortality rate in the sample of gang-members reaches $20 \%$, with the probability of death increasing with initial involvement in gang violence and with personality traits associated with unruliness.

JEL Classification: J4, K42, O15, O17

Keywords: crime, youth, gangs, drugs, trafficking, Brazil

Corresponding author:

Rodrigo R. Soares

PUC-Rio

Departamento de Economia

Rua Marquês de São Vicente, 225 - Gávea

Rio de Janeiro, RJ - 22451-900

Brazil

E-mail: soares@econ.puc-rio.br

\footnotetext{
* The authors wish to thank Guilherme Hirata for outstanding research assistance. This paper benefited from comments from Giovanni Mastrobuoni, Yaw Nyarko, and seminar participants at RAND Corporation, the 2011 World Bank's ABCDE Conference (Paris), and the LACEA 2012 Annual Meeting (Lima).
} 


\section{Introduction}

Youth account for a disproportionally high fraction of the perpetrators and victims of violence (see, for example, Levitt and Lochner, 2001 and Soares, 2006). Part of this involvement with violence is associated with membership to criminal groups, as exemplified by the Crips and Bloods in the 1980s' Los Angeles, the pandillas and maras in several Latin American countries and throughout the US penitentiary system, and the drug-trafficking gangs in the favelas (slums) of Rio de Janeiro. Information on the activities and organization of these groups and on the individuals involved with them is extremely rare. In the particular case of Brazil, a country with high violence and strong presence of drugtrafficking gangs in poor areas of virtually every major urban center, very little is known about the way they function.

A greater understanding of how criminal organizations attract the youth and how they operate is paramount in designing an effective strategy to fight crime and curb violence, but the difficulty in "getting inside" these criminal organizations has been a major obstacle. The handful of studies that have been able to overcome this obstacle have made important contributions. With a more historical perspective, Reuter (1983) and Gambetta (1993) studied the organization and functioning of the Italian Mafia, while Leeson (2007) discussed the governance rules among $18^{\text {th }}$ century pirates. Directly related to this paper, there is also a considerable literature on the contemporaneous phenomenon of urban gangs, most of a descriptive nature and with an ethnographic approach. Examples include Moore (1990), who discussed the role of gangs in violence and the drug trade, Levitt and Ventakesh (2000 and 2001), who analyzed the financial organization and history of a drug-selling gang and the outcomes of a cohort of youth growing up in the Chicago projects, Dowdney (2003), who described the structure and social norms of gangs in favelas of Rio de Janeiro, and Rubio (2007), who coordinated an impressive effort to survey the perceptions and involvement of youth with pandillas and maras in Guatemala, Honduras, Nicaragua, and Panama. Still, little is known about the selection of youth into these gangs, the occupational structure of these organizations, and the typical "careers" of gang-members.

This paper uses a unique dataset to help fill in this gap. In 2004, a Brazilian NGO, Observatório de Favelas, interviewed 230 individuals who worked for drug-selling gangs in 34 favelas of Rio de Janeiro. $^{1}$ The survey collected detailed information on characteristics of both gang-members (demographics, socioeconomic background, etc.) and their jobs (wages, hours, occupation, involvement with violence, etc.). Gang-members were between 11 and 24 years old when first interviewed from June

\footnotetext{
${ }^{1}$ Observatório de Favelas translates as Slum Observatory. Favela is used in the remainder of the paper to refer to Brazilian slums. The Observatório de Favelas (www.observatoriodefavelas.org.br) is an NGO founded by individuals originally from poor communities in Rio de Janeiro, focused on research and policy action to promote knowledge, public debate, and policy proposals on issues relevant to the favelas and other urban phenomena.
} 
to August of 2004. After this baseline interview, interviewers attempted - with limited success - to follow individuals monthly for the four subsequent months. In addition, death records were collected for the two-year period following the baseline interview. The data allow us to draw an unprecedented picture of the criminal entry, career, and exit among gang members. Despite limitations associated with the non-random nature of the sample, the data provide an insight into drug-trafficking gangs that represents an important progress in our understanding of the way these groups function.

This paper makes four main contributions. First, we describe in detail the characteristics of the drug-trafficking jobs that existed in the favelas of Rio de Janeiro in 2004. We document that gangmembers earned on average $\$ 300$ per month, only $23 \%$ more than other youth from the favelas, and worked typically more than 10 hours a day. There were large risks associated with these jobs. At the time of the first interview, more than half of the sample had participated in armed confrontations with rival gangs and roughly two-thirds had participated in gun fights with the police. At the end of two years, $20 \%$ of the initial sample had died. We also document how job characteristics vary according to occupation within the gang. We show, for example, that the risks are even larger for members higher up in the drug-trafficking hierarchy. Members at the top of the hierarchy earned $90 \%$ more than members in entry-level occupations, but were also 10 percentage points more likely to die within two years.

Second, we investigate who the young men who voluntarily join drug-trafficking gangs are. We combine data from the 2000 Brazilian Census with the survey of gang-members and use the procedure suggested by Lancaster and Imbens (1996) for contaminated samples. This allows us to estimate a model of selection into the criminal sector to investigate what distinguishes gang-members from other young men living in the favelas of Rio de Janeiro that chose not to join a gang. This is one of the first estimates of determinants of participation in criminal activities available for Latin America. We find that younger individuals, from lower socioeconomic background (black, illiterate, and from poorer families) and with no religious affiliation are more likely to join drug-trafficking gangs. For example, blacks are between 6 and 17 percentage points more likely to join a drug-trafficking, while the same number for illiterates is between 6 and 20 percentage points.

The third contribution of the paper is to analyze the determinants of wages in drug-trafficking jobs. We present what we believe to be the first set of Mincerian regressions for individuals employed by criminal organizations. We find that there are no returns to schooling within the gangs, but there are strong returns to experience, bravery, and loyalty. Each additional year working for a gang is associated with a $10 \%$ increase in wages, while participation in an armed conflict increases wages by $5 \%$ and a punishment for failing to comply with gang rules reduces wages by $17 \%$. 
Finally, the paper also examines the "career path" of criminals: age at entry, progression within the gang hierarchy, and short to medium term outcomes. We find that troubled kids who have problems at school and start using drugs early on are at greater risk of being recruited at younger ages. In line with the evidence from the wage equations, we also document that position within the gang hierarchy is positively correlated with experience and with participation in gun fights. Finally, we present evidence that gang-members with weaker attachment to the gang and better outside opportunities are more likely to quit the gang. For those who choose to continue in the gang, prospects are bleak. Each additional experience of gun fight at the time of the initial interview is associated with an increase of 2 percentage points in the probability of death in the following two years. Individuals with personality traits associated with aggressiveness and lack of control are also more likely to die.

Our paper speaks to several streams of literature. There is a large literature on the relationship between human capital and crime, with an almost exclusive US focus. Part of this literature analyzes the short-run effects of schooling, through incapacitation of children and teenagers, on the incidence of crime (Snyder and Sickmund, 1999, Jacob and Lefgren, 2003, Gottfredson and Soulé, 2005, Luallen, 2005), while other papers evaluate the long-run effects of education on criminal involvement through better legal market opportunities and possibly changed preferences (Lochner and Moretti, 2004, Deming, 2011, Lochner, 2010, Machin et al, 2010). Other relevant work includes studies on criminal careers (see review on Blumstein et al, 1986) and on violence in connection with drug-trafficking (see papers in De La Rosa et al, 1990). In the case of Brazil, NEPAD \& CLAVES (2000), Neto et al (2001), Sousa and Urani (2002), Dowdney (2003), and Observatório de Favelas (2006) present ethnographic analyses of drug-trafficking gangs in the favelas of Rio de Janeiro that can be seen as complementary to the current study. ${ }^{2}$

As mentioned before, our work is most closely related to the literature on the structure and role of criminal organizations (Reuter, 1983, Moore, 1990, Gambetta, 1993, Levitt and Venkatesh, 2000, Leeson, 2007, and Rubio, 2007). The contribution of the current study is to focus on individual gangmembers and their careers. We have a unique dataset with a wealth of individual characteristics that allows us to paint a picture of the background and career of gang-members that, up to now, had been impossible. Among other things, we present what we believe to be the first set of results related to wage and occupational determinants within criminal organizations.

The remainder of the paper is structured as follows. Section 2 presents the data and describes the characteristics of drug-trafficking jobs and of gang-members. Section 3 introduces a selection model,

\footnotetext{
${ }^{2}$ The topic of this paper also bears some relationship with the literature on child combatants in contexts of civil war, such as exemplified by Blattman and Annan (2008 and 2010).
} 
which we estimate by combining data from the gang-members survey with the 2000 Brazilian Census. In section 3, we estimate Mincerian equations for drug-trafficking jobs. In section 4, we examine the "career path" of criminals, analyzing their entry, progression within the gang hierarchy, and short to medium term outcomes. Section 5 concludes the paper.

\section{Data and Descriptive Statistics}

Rio de Janeiro is an important transit point for cocaine exports to Europe and South Africa (UNODC, 2012) and a regional distribution point for cocaine and marijuana. The city also has an active retail market controlled by drug-trafficking gangs operating in some of its 600 favelas. ${ }^{3}$ The gangs are armed groups formed by young men living in the favelas in which the retail markets operate.

This study relies on unique data collected by the Brazilian NGO Observatório de Favelas (OF) on 230 individuals who worked for the drug-trafficking business in favelas of Rio de Janeiro, Brazil, when first interviewed between June and August of $2004 .^{4}$ The baseline interviews collected detailed information on demographics, family background, and criminal activities. The NGO attempted to follow individuals for a period of four months after the initial interview. Death records covering the two years subsequent to the baseline interview were also collected. Given the difficulty in reaching the population of interest, the study adopted a convenience sampling scheme, where the selection of interviewees was based primarily on the connections that interviewers had to the drug-trafficking network. To conduct the survey, the NGO selected 10 interviewers (5 men and 5 women) who had had some previous relationship to drug gangs. ${ }^{5}$ Some of them had worked for a criminal organization before, while others were in contact with individuals employed by the drug-trafficking business. Representativeness was also taken into consideration when selecting the interviewers: the 230 interviewees worked in 34 different

favelas, geographically distributed across the city. Each interviewer was supposed to survey between 20 and 25 individuals.

In our analysis, we use several variables constructed using data from the OF survey. These convey the information listed below and can be broadly classified into the following categories:

- individual demographic characteristics: age, race, years of schooling, and illiteracy;

\footnotetext{
${ }^{3}$ According to the 2010 Brazilian Census, approximately 1.4 million people, $22 \%$ of the city's population, live in favelas. Depending on the criterion used to define a favela, it is estimated that there are either 868 or 600 favelas in the city of Rio de Janeiro.

${ }^{4}$ The specific timing was the following: 7 interviewers conducted 157 interviews in June $2004 ; 2$ other interviewers conducted 53 interviews in July; and 1 interviewer conducted 20 interviews in August.

${ }^{5}$ All interviewers with the exception of one had completed high school, 3 were going to college at the time of the survey, and one had graduated from college.
} 
- family background: whether individual was raised in a female single-headed household, number of siblings, ownership of real estate, and occurrence of domestic violence;

- drug-trafficking jobs characteristics: age at entry, years of experience, monthly wage, and occupation;

- history of violence and attachment to the gang: number of previous participations in armed confrontations with rivals or with the police, possession of weapon during work time, and whether individual had previously stopped working for the drug-trafficking gang;

- individual personality and behavioral traits: whether individual was perceived as unruly by his family, age at which started using drugs, and whether individual was religious.

The interpretation of each of these variables is discussed when they are introduced in our empirical analysis. For purposes of comparison with the average population of the city and to analyze the selection into the gang, we also use individual level variables from the 2000 Brazilian Census: race, age, illiteracy, real estate ownership by the family, and religiosity. We choose the 2000 Census because it corresponds to the closest point in time for which we have data on households living in the favelas. ${ }^{6}$

We start in this section by describing the characteristics of gang-members and the occupational features associated with drug-trafficking jobs. Given the scarcity of information on the subject, we believe this descriptive characterization has enough value to warrant a detailed discussion.

\subsection{Characteristics of Individuals Employed in Drug-Trafficking Jobs}

Almost all gang-members interviewed were males (225, or 98\%). They were between 11 and 24 years-old at the time of the baseline interview (average age of 16, and 67\% between 16 and 18), with 9\% married, 28\% with kids, but $67 \%$ still living with a parent. Only $37 \%$ had been raised by both parents and the father had been involved in the upbringing in fewer than $40 \%$ of the cases $(23 \%$ of the 230 reported that their fathers were deceased, while more than $10 \%$ did not know whether the father was still alive). The mother had been involved in the upbringing of $81 \%$ of them. They had on average 2.7 siblings, with $22 \%$ having 4 siblings or more. Drug problems in the family, as well as domestic violence, were relatively common: $30 \%$ reported having a sibling with drug problems, $10 \%$ having an addicted father, $7 \%$ an addicted mother, and $23 \%$ reported having been a victim of domestic violence.

Despite the fact that $88 \%$ were below 18 years-of-age, only $10 \%$ were attending school. Schooling outcomes at the time of the interview can be summarized as follows: $15 \%$ dropped out before completing elementary school (without retention, a child in Brazil should complete elementary school

\footnotetext{
${ }^{6}$ There were no major economic changes in Brazil between 2000 and 2004, period which predates the more recent acceleration in growth experienced by the country. According to the Penn World Tables, for example, income per capita in Brazil between 2000 and 2004 grew by $4 \%$ only (total growth accumulated over the period).
} 
by age 11); 70\% finished elementary school but did not graduate from middle school; $10 \%$ graduated from middle school; and only 5\% graduated from high school. Among the drop-outs, 57\% had left school before turning 15 and 35\% had dropped out between ages 15 and 16. Roughly 60\% reported having had a previous legitimate job before working for the gang. One reason why these individuals may have dropped out of school at early ages is because they started working for the drug business also very young: $8 \%$ started before age 13, 58\% started between 13 and 15, and less than $2 \%$ started after 18 .

\subsection{Characteristics of Drug-Trafficking Jobs}

Table 1 presents the characteristics associated with drug-trafficking jobs in our sample. Average monthly wages were around US\$ 300. Individuals were very young, on average around 17, and worked typically more than 10 hours a day, with roughly one day-off every two weeks. The vast majority of individuals carried a gun at work, but some only sporadically.

A large fraction of them had trouble with the police: $28.5 \%$ had gone through juvenile detention and $53 \%$ had been arrested at least once. The majority reported having been victims of police violence and extortion. There was also a history of direct involvement with violence. Many took part in gun fights both with the police and with rival gangs, $18 \%$ had committed at least one homicide, and $23.9 \%$ had been wounded in shoot-outs; $24 \%$ had carried out a castigo, i.e., a physical punishment that is applied to residents of the favela - including gang-members - for breaking the rules imposed by the gang; and $22.3 \%$ reported having been a victim of physical punishment. ${ }^{8}$

Maybe the most striking information in Table 1 is the mortality rate of those employed in drugtrafficking jobs. Two years after the initial interview, 45 individuals, or roughly $20 \%$ of the sample, had died; 40 of them had been killed. ${ }^{9}$ To put it in perspective, this number is higher than the mortality rates of military personnel in severe conflict areas. For example, less than $1 \%$ of the American military personnel fighting in the Vietnam War were killed (Leland and Oboroceanu 2010). ${ }^{10}$ Death rates are typically higher, however, in settings involving youth at risk. Levitt and Venkatesh (2001) follow a cohort of men coming of age in a Chicago housing project in 1991 and record a 10-year mortality rate above $10 \%$ for individuals aged between 17 and 26 at the time of the first interview, in a sample that includes both gang-members and others. In a previous work, Levitt and Venkatesh (2000) estimate the

\footnotetext{
${ }^{7}$ The information on earnings is provided in brackets defined in terms of multiples of the monthly minimum wage, while the information on hours is provided in brackets of daily hours. We translate these variables into scalars by choosing the midpoint in each bracket, and an equivalent distance above the last bracket. We use an exchange rate of 2 R $\$ / U S \$$.

${ }^{8}$ Punishments may involve being shot in the hands or feet, beatings or death (Dowdney 2003). A gang member may suffer punishment for misappropriation of gang money or drugs or for committing a theft in the favela (Souza e Silva et al 2006).

${ }^{9}$ Of the remaining five, two died of overdose, two were ran-over during armed robberies, and one died in a car accident.

${ }^{10}$ For example, according to Leland and Oboroceanu (2010), the total casualty rate - deaths plus injuries - among American military personnel during the Vietnam war was $4.1 \%$; death rate alone was below $1 \%$.
} 
four-year mortality rate for members of a Chicago drug-selling gang to be of the order of $28 \%$, with the average number of non-fatal injuries over the same period reaching 2.4 per gang-member, and the average number of arrests being close to 6 . Also in their setting, gang activity is an extremely risky business.

All these patterns point to the necessity of better understanding the decisions of youth to join drug-trafficking gangs in different contexts. The evidence available, both in Brazil and in the US, make it hard to rationalize these decisions from a purely monetary perspective. Though issues of social status within the local communities may be important, it is also possible that behavioral aspects associated with lack of self-control and time-inconsistency may play some role. In fact, Lee and McCrary (2005) present evidence on criminals' behavior consistent with the existence of hyperbolic discounting.

The last four columns in Table 1 present the same descriptive statistics by occupation in the drug-trafficking business. Dowdney (2003) argues that in each favela the drug gang operates as a strict hierarchical structure with well-defined occupations and that such structure is repeated very similarly in all favelas. Following the structure outlined in Dowdney (2003), we categorize our data into four occupational levels: (a) occupation 1: look-outs (observe the area to warn of a police raid or a rival gang invasion) and local transporters (move small quantities of drugs within a favela); (b) occupation 2: street-sellers (sell drugs directly to consumers) and wrappers (handle and wrap the drug before sale to consumers); (c) occupation 3: soldiers (responsible for local security and also for the main role in armed confrontations); and (d) occupation 4: managers (depending on the level, accountable for the entire operation in a favela or for the market for one specific drug). The distribution across occupations in our sample is as follows: $20.2 \%$ were look-outs and transporters; $42.6 \%$ were street-sellers and wrappers; $24.8 \%$ were soldiers; and only $12.4 \%$ were managers.

Our data provide support for the hierarchic structure proposed by Dowdney (2003). Managers are older (17.7 years old), have longer tenure in the gang (2.6 years of experience) and earn higher wages than street-sellers, wrappers and soldiers, which, in turn, are older (16.8 years old for both occupations), have greater experience (2.1 for street-sellers and 1.8 for soldiers) and earn more than look-outs and local transporters (16 years old with 1.5 years of experience). Thus, look-outs and local transporters seem to be the entry level occupations in the gang, while managers sit at the top of the hierarchy. The ranking between occupations 2 and 3 is less clear. The wage, age, and tenure of the two occupations are similar.

Table 1 shows that involvement with violence increases as we move in the occupational structure from look-outs and transporters to street-sellers and wrappers, then to soldiers and to managers. While 
less than $30 \%$ of those in lower level occupations claim to carry a gun at work on a daily basis, $78 \%$ of managers report working armed. Similarly, soldiers and managers are more likely to have participated in gun fights with police and rival gangs, to have carried out punishments, to have committed homicide, to have been wounded in combat, and to have been killed in the two years following the initial interview. Finally, soldiers and managers are less likely to have been punished for bad behavior, consistent with the idea that these positions reflect a higher status within the gang and, therefore, require a history of compliance with gang's rules.

The high risks - of being arrested and/or victim of police violence, of being wounded in armed conflicts with the police and with rival gangs and, most important, of being killed - associated with the drug-trafficking jobs beg the question of why these young men join the drug-trafficking ranks in the first place. Dowdney (2003) argues that children and adolescents are not forced or coerced to join a gang. Consistent with this view, $39 \%$ of the sample reported having voluntarily stopped working for the drug business at some point in the past. Roughly half of the sample mentioned they had been introduced to the gang by a friend or a family member.

When asked what had led them to join the drug-trafficking gang, "to make a lot of money" and "to financially support my family" were presented as the main reasons. These were also presented as the main reasons for why they remained in the gang (together with "connection to the drug gangmembers"). Finally, when pressed to think about reasons that would make them quit, "earn a lot of money doing something else" and "find a legitimate job" were the main answers for, respectively, 50\% and $30 \%$ of the respondents (not shown in the table).

\subsection{Comparing Individuals Employed in Drug-Trafficking Jobs to Young Men Living in Favelas}

In Table 2, we compare individuals in the sample of gang-members to young men residing in the favelas of Rio de Janeiro. The Brazilian Census classifies favela areas as "subnormal urban agglomerates," allowing identification of the households located in favelas of a given city. We use the 2000 Census files to construct descriptive statistics for the population between 10 and 25 years-of-age in favela areas of Rio de Janeiro.

We concentrate the comparison and the remainder of our analysis on males because they correspond to $98 \%$ of our sample of gang-members, which is consistent with evidence that victims and perpetrators of violence in Brazil are predominantly young males (see, for example, Cerqueira and Soares, 2012). Table 2 presents the set of variables that can be compared across the Census and the 
gang-members datasets: individual characteristics related to race, religion, marital status, age, education, labor market status, and earnings. ${ }^{11}$

Gang-members earned on average $23 \%$ more than other young men living in the favelas. ${ }^{12}$ The counterfactual wages of gang-members may be somewhat lower than the wage of the average young man living in a favela, given that gang-members are more likely to be black, illiterate, and younger, characteristics that are penalized in the legal labor market. Finally, the $12 \%$ unemployment rate among young men living in favelas may also increase the attractiveness of drug-trafficking jobs. Gang-members also have characteristics indicating a higher probability of being at risk: they are 6 percentage points more likely to be illiterate, 44 percentage points less likely to be attending school, 5 percentage points more likely to be married at such young ages, and 19 percentage points less likely to be religious.

We proceed next to compare the socioeconomic status (henceforth, SES) of gang-members' families to the SES of families of young men living in favelas. One complicating factor for such comparison is that in the Census we can only observe the parents' SES if the young man still lived with his parents, which is a selected sample of young men living in favelas. For this reason, we use as comparison group men between ages 25 and 65 and women between ages 25 ages 60 living in favelas, who would have been old enough to be parents of the young men surveyed in the OF sample (see Appendix Table A1).

The limited evidence we have suggests that gang-members come from lower SES families. The comparison indicates that the mothers of gang-members had on average 0.8 less years of schooling than women aged 25-60 living in favelas. The income of families living in favelas (in which either the head or the head's spouse was a man aged 25-65 or a woman aged 25-65) was on average $26 \%$ higher than the parental income of gang-members. Gang-members also came from larger families with 1.4 more children and were 15 percentage points more likely to have been raised by a single mother.

These results should be interpreted with caution given the limitations of the data. First, a large fraction of individuals interviewed in the OF sample did not know their parents' income or schooling: $36 \%$ failed to report their mother's education and $29 \%$ did not answer about their parents' income. Another issue concerns the identity of the survey respondent: while in the OF survey gang-members were reporting the schooling and the income of their parents, the household head or the head's spouse may have reported this information when interviewed by the Census. Finally, some of these characteristics may not be directly comparable. For example, in the OF survey respondents were asked a

\footnotetext{
${ }^{11}$ Values from the 2000 Census are deflated to June 2004 and then converted into US dollars.

${ }^{12}$ The monthly minimum wage at the time was 260 Brazilian Reais, or roughly US\$ 130.
} 
retrospective question about whether they had been raised by their mother only while in the Census we can identify the fraction of families in which the head is a single female.

In the following sections, we investigate in more detail the relationship between individual characteristics and criminal careers. First, we study the issue of selection into the criminal career and investigate the determinants of drug-trafficking wages. We then proceed to analyze the determinants of the typical career - entry, progression, and exit - in the gang.

\section{Selection and Wages in Drug-Trafficking Jobs}

\subsection{Model and Empirical Strategy}

All the young men living in a favela in which a drug-trafficking gang is active face the same decision: whether to join the gang or not. The members of a gang are recruited from young men living in the favela in which the gang operates and to all accounts any young man can join the drug-trafficking ranks. If so, why did some young men decide to work for the drug-trafficking business while some of their peers did not? Are their families different in any peculiar way? Are they distinguishable from other youth? Would it possible to tell, beforehand, who are the children most likely to follow a criminal path? We tackle this question by developing a model of selection into drug-trafficking jobs that makes use of data from the OF survey and from the 2000 Brazilian Census.

The analysis of the decision to participate into crime gains additional relevance in light of the evidence from the US. Blumstein et al (1986), for example, document a great heterogeneity in participation into crime across demographic groups (extensive margin decision across gender, age, race, and socioeconomic background), but a striking homogeneity in the level of criminal activity for those who do participate (intensive margin). In other words, to understand the dynamics and the determination of criminal involvement, the extensive margin (entry and exit of individuals) seems to be much more relevant than the intensive margin (level of criminal activity of an individual involved with crime).

Suppose there are two sectors that workers can choose: an illegal sector denoted by the subscript $I$ and a legal sector denoted by the subscript $L$. Earnings in the illegal sector are determined according to

$$
\ln w_{j, I}=x_{j}^{\prime} \beta_{I}+\varepsilon_{j, I},
$$

where $x_{j}$ is a vector of characteristics of individual $j$ and $\varepsilon_{j, I} \sim N\left(0, \sigma_{I}^{2}\right)$. Similarly, earnings in the legal sector are determined according to

$$
\ln w_{j, L}=x_{j}^{\prime} \beta_{L}+\varepsilon_{j, L},
$$


where $\varepsilon_{j, L} \sim N\left(0, \sigma_{L}^{2}\right) . \beta_{I}$ and $\beta_{L}$ are the returns to individual characteristics in the illegal and legal sectors, respectively. In principle, some entries of $\beta_{I}$ and $\beta_{L}$ may be zero, such that some characteristics are valued in one sector but not in the other. Worker $j$ will choose to work in sector $I$ if illegal earnings are sufficiently higher than legal earnings to compensate for potential negative characteristics associated with illegal jobs:

$$
\ln w_{j, I} \geq \ln w_{j, L}+\alpha_{j}
$$

where $\alpha_{j}$ indicates the compensating differential related to the risks associated with illegal jobs and the moral conflicts that some may face when working in illegal occupations. The weight attributed to the risk and moral dimensions of illegal activities may depend on individual characteristics, so that we write:

$$
\alpha_{j}=z_{j}^{\prime} \delta+v_{j}
$$

where $z_{j}$ indicates a set of demographic characteristics and $v_{j}$ a non-observable component with $v_{j} \sim N\left(0, \sigma_{v}^{2}\right)$. In principle, $z_{j}$ may contain some of the same elements of $x_{j}$ and other components (variables related to risk aversion and moral views on crime, for example, could enter $z_{j}$ but not $x_{j}$ ).

Under these assumptions, the probability that worker $j$ works in the illegal sector is given by:

$$
\operatorname{Pr}\left(Y_{j}=1 \mid x_{j}, z_{j} ; \beta, \gamma\right)=\Phi\left(x_{j}^{\prime} \beta+z_{j}^{\prime} \delta\right)
$$

where $Y_{j}$ is an indicator variable that is equal to 1 if individual $j$ is employed in the illegal sector and 0 otherwise, and $\beta=\beta_{I}-\beta_{L}$.

One challenge to the estimation of the participation equation (5) is that we do not have a dataset in which we observe simultaneously individual characteristics and whether the individual is employed in the legal or illegal sectors. Instead, we have two independent samples. The first is drawn from the subpopulation who chose to work in the illegal sector (i.e., $Y=1$ ). These data come from the OF survey that interviewed young men employed in the drug business. The second sample is a random sample of the population of young men living in favelas for whom only covariates are observed - that is, we do not observe whether these workers are employed in the illegal or in the legal sector. These data come from the 2000 Brazilian census. We use the variable $S_{j}$ to distinguish the two samples: $S_{j}$ is equal to 1 if the data on individual $j$ come from the OF survey and 0 if they come from the Census. Let $N_{1}$ be the number of observations in the OF sample, $N_{0}$ the sample size of the Census sample, and $q$ denote the fraction of the overall population employed in the illegal sector. 
Lancaster and Imbens (1996) propose a generalized method of moments (GMM) estimator for equation (5) when $q$ is known. They assume that the relative sizes of the two samples are determined by a sequence of Bernoulli trials with unknown parameter $h$ and consider the following moments:

$$
\begin{aligned}
& m_{1}(\beta, \delta, q, h, S, x, z)=\left(\begin{array}{l}
x \\
z
\end{array}\right)\left[S-\frac{\frac{h}{q} \Phi\left(x_{j}^{\prime} \beta+z_{j}^{\prime} \delta\right)}{1-h+\frac{h}{q} \Phi\left(x_{j}^{\prime} \beta+z_{j}^{\prime} \delta\right)}\right] \frac{\phi\left(x_{j}^{\prime} \beta+z_{j}^{\prime} \delta\right)}{\Phi\left(x_{j}^{\prime} \beta+z_{j}^{\prime} \delta\right)}, \\
& m_{2}(\beta, \delta, q, h, S, x, z)=-\frac{1}{q}\left[S-\frac{\frac{h}{q} \Phi\left(x_{j}^{\prime} \beta+z_{j}^{\prime} \delta\right)}{1-h+\frac{h}{q} \Phi\left(x_{j}^{\prime} \beta+z_{j}^{\prime} \delta\right)}\right], \\
& m_{3}(\beta, \delta, q, h, S, x, z)=h-\frac{\frac{h}{q} \Phi\left(x_{j}^{\prime} \beta+z_{j}^{\prime} \delta\right)}{1-h+\frac{h}{q} \Phi\left(x_{j}^{\prime} \beta+z_{j}^{\prime} \delta\right)} .
\end{aligned}
$$

They show that $\hat{\beta}, \hat{\delta}$ and $\hat{h}$, which equate the sample moments $\hat{m}$ to zero, are consistent estimators of $\beta, \delta$ and $h$ :

$$
(\hat{\beta}, \hat{\delta}, \hat{h})=\arg \min _{\beta, \delta, h}\left(\begin{array}{c}
\widehat{m}_{1} \\
\widehat{m}_{2} \\
\widehat{m}_{3}
\end{array}\right)^{\prime}\left(\begin{array}{l}
\widehat{m}_{1} \\
\widehat{m}_{2} \\
\widehat{m}_{3}
\end{array}\right) .
$$

We estimate the participation equation (5) through GMM using their proposed estimator, providing different estimates for different values of $q$. Here we give some intuition for their estimator by looking at the simplest case possible, when there is only one dichotomous independent variable. Suppose we are interested in identifying $\operatorname{Pr}(Y=1 \mid x=1)$. Notice that $\operatorname{Pr}(Y=1)=q, \operatorname{Pr}(x=1 \mid Y=$ 1) and $\operatorname{Pr}(x=1)$ are all known. From Bayes' rule, we can estimate:

$$
\operatorname{Pr}(Y=1 \mid x=1)=\frac{\operatorname{Pr}(x=1 \mid Y=1) \operatorname{Pr}(Y=1)}{\operatorname{Pr}(x=1)}
$$

The second goal of our empirical analysis is to estimate the wage equation (1) for the illegal sector. Because youth who self-select into the illegal sector may be very different from the population at large, ordinary least squares are potentially biased. To correct for self-selection, we use Heckman's twostep method. After estimating the participation equation (4), we estimate the following modified wage equation:

$$
\ln w_{j, I}=x_{j}^{\prime} \beta_{I}+\alpha_{I} \lambda\left(x_{j}^{\prime} \widehat{\beta}+z_{j}^{\prime} \hat{\delta}\right)+u_{j, I},
$$


where $\lambda\left(x_{j}^{\prime} \widehat{\beta}+z_{j}^{\prime} \hat{\delta}\right)=\frac{\phi\left(x_{j}^{\prime} \widehat{\beta}+z_{j}^{\prime} \widehat{\delta}\right)}{\Phi\left(x_{j}^{\prime} \widehat{\beta}+z_{j}^{\prime} \widehat{\delta}\right)}$ is the Inverse Mills' Ratio calculated using the estimated coefficients $\widehat{\beta}$ and $\hat{\delta}$ obtained from the estimation of the participation equation.

\subsection{Selection into Drug-Trafficking}

Table 3 presents the results associated with the participation equation (5). To the best of our knowledge, this is one of the first set of estimates on the determinants of participation in criminal gangs available for Latin America. GMM estimates are reported in Panel A while Panel B shows the marginal effects. The table shows results for different values of $q$-i.e., for different assumptions about which fraction of young men living in favelas was working for the drug-trafficking business, namely 5\%, 10\% and 15\%. Dowdney (2003) estimates that $1 \%$ of residents of Rio de Janeiro's favelas are employed by the drug-trafficking business. According to the 2000 Brazilian Census, the population of men between 10-25 corresponded to $15.4 \%$ of the total population living in Rio de Janeiro's favelas. These two figures together suggest that $6.5 \%$ of men ages 10-25 living in favelas were members of drug-trafficking gangs. This is a relatively small number compared, for example, to the Chicago neighborhood analyzed by Levitt and Venkatesh (2000), where a quarter of the males between 16 and 22 were estimated to work as foot-soldiers for the gang. Rubio (2007), looking at Central American countries, reports a participation rate in pandillas among individuals of lower socioeconomic background of $5 \%$ for individuals enrolled in school and of $17 \%$ for those who dropped out.

We focus our attention on Panel B for ease of interpretation. The first specification includes only a dummy for black and age. In the second specification, we add a dummy for illiteracy. The third specification includes in addition a dummy for whether the family owned the house in which the gangmember lived, a proxy for the socioeconomic status of the individual's family. Finally, in the last specification, we add a dummy for whether the individual was not religious. It is apparent from the table that the magnitudes of the estimates vary with $q$, but the results are qualitatively the same irrespective of the assumption on the fraction of gang-members.

The table indicates that individuals with fewer opportunities in the legal labor market are more likely to select into the illegal sector: black, young, and illiterate men are the ones at highest risk of working for the drug-trafficking gang. Depending on the assumption about $q$, blacks are from 617 percentage points more likely to work for the gang, while the illiterate are 6 to 20 percentage points more likely. Consistently with this pattern, young men from poorer socioeconomic backgrounds (proxied by ownership of the house) are also more likely to work for the drug-trafficking business. Finally, young men that reported having no religion were from 4 to 13 percentage points more likely to be part of a drug-trafficking gang. Overall, the qualitative pattern of correlation between socioeconomic 
background and participation into crime is broadly consistent with the evidence available from other settings, such as that presented by Blumstein et al (1986) and Rubio (2007). ${ }^{13}$

\subsection{Wages}

In this section, we investigate the determinants of criminal productivity within the gang. We proceed with two exercises. First, we follow the model from section 3.1 and estimate a Mincerian equation for the illegal sector, accounting for the possibility of selection into the gang. We run a regression of the natural logarithm of wages on the first four variables from Table 3 - namely race, age, illiteracy, and ownership of real estate by the family - while controlling for the Inverse Mills' Ratio implied by the most complete specification in Table 3. The variable excluded from the wage regression is a dummy for being religious, implying that the identifying assumption is that religion affects the probability that the individual joins the gang, but, conditional on joining the gang, religion does not affect wages. While this analysis takes into account selection, it restricts us to using information that are available both in the OF and in the Census datasets.

In our second exercise, we depart from the model outlined in section 3.1 to further explore the wealth information available in the OF survey. We begin by running specifications similar to those typically used in labor economics, regressing the natural logarithm of wages on race, experience, years of schooling and age at which one had started working for the drug gang. We also include in this benchmark specification a set of controls for family background, namely whether the individual was raised by a single mother, whether the family owned the house where he lived, and number of siblings. We then extend this traditional specification by including variables that may be particularly important for productivity and career advancement in crime: a dummy indicating whether the individual had a physical disability, a variable indicating the number of times that the individual had participated in armed confrontations with rival gangs or with the police, and another dummy variable indicating whether he had ever been physically punished for breaking the gang's rules. Finally, we include occupational dummies indicating different positions within the gang hierarchy. Again, to the best of our knowledge, these two sets of results are the first estimates of Mincerian regressions for individuals employed by criminal organizations.

Table 4 presents the results of the first exercise, in which we keep only the variables used to estimate the selection equation. The table contains four panels, each representing a different assumption concerning the selection correction. In the first panel, there is no correction for selection, while in the remainder three panels we include the Inverse Mills' Ratio corresponding to the three models estimated

\footnotetext{
${ }^{13}$ Even though Rubio (2007) documents a significant correlation with socioeconomic only for individuals with lower educational levels.
} 
in Table 3, respectively: $q=5 \%, q=10 \%$, and $q=15 \%$. In each panel, the first column includes only race and age as explanatory variables; the second column includes in addition a dummy for illiteracy; and the third column includes also a dummy indicating ownership of the house by the family.

Qualitative results across the four panels are identical: age and illiteracy are positively correlated with wages, while race and ownership of real state by the family are not. Wages exhibit a very steep profile within the gang, with a roughly $10 \%$ increase associated with each additional year. Surprisingly, illiteracy also appears positively correlated with wages. Since we do not control for actual experience within the gang in these specifications, it is possible that, conditional on age, illiteracy is correlated with a longer tenure in the drug-trafficking business (indicating earlier drop-out from school and entry into the gang). If anything, education seems to reduce the attractiveness of illegal occupations.

The other important result to come out of Table 4 is that selection into the drug-trafficking gang does not seem to affect much the estimated coefficients in the wage regressions. The coefficients on age are almost identical across the four panels, while those on illiteracy increase by roughly $20 \%$ when the Inverse Mills' Ratio is included, but remain unchanged irrespectively of the assumption on $q$. Given these results, it looks as if selection into crime is not a serious enough hindrance to the estimation of wage regressions for the illegal sector, even more so if one controls for a broad set of characteristics.

With these results in mind, we move to Table 5 in which we estimate Mincerian regressions ignoring selection and exploring in more detail the wealth of information from the OF survey. The first column includes only the individual characteristics and family background variables described before. Columns 2 to 4 include, in sequence, a dummy for physical disability, the number of times the individual participated in armed confrontations, and a dummy indicating whether he had been physically punished for breaking gang's rules. Column 5 includes all these three variables simultaneously. Column 6 goes back to the benchmark specification, but now including dummies for occupations, and column 7 includes all independent variables simultaneously.

The first result to come out of Table 5 is that there are no returns to education within the gang. The estimated coefficients are very close to zero and are precisely estimated. There is also no penalty for being black and no returns to family background (being raised by a single mother appears as borderline significant in some specifications, but this significance disappears as other controls are included). There are, however, high returns to experience. In the first specifications, each additional year working for the gang is associated with a $10 \%$ increase in wages. Age at entry into the gang, in turn, is also positive and large in magnitude: conditional on experience within the gang, having entered later is associated with 
higher wages. This may reflect the fact that there is a negative selection on unobservables for individuals who enter very young into the gang.

Columns 2 to 5 show which individual characteristics the gang rewards. The lack of a physical disability, a proxy for physical prowess, is associated with a wage premium of $37 \%$. The number of armed confrontations in which the individual had participated, which supposedly reflects both combat experience as well as the skills required to have survived, is also associated with higher wages. Each additional conflict is associated with a 5\% increase in wages. Finally, obedience to the gang's rules is also rewarded. Members who reported having been physically punished at least once for failing to comply with such rules experienced a $17 \%$ wage penalty.

In the last two columns of Table 5 we include dummies for occupation within the drugtrafficking hierarchy. The results confirm the structure discussed above. Managers earn higher wages than street-sellers, wrappers and soldiers, which, in turn, earn higher wages than lookouts and transporters. Conditional on observables, managers earn typically $35 \%$ more than members in entrylevel occupations. We cannot reject the hypothesis that street-sellers and wrappers are paid as much as soldiers. When the occupational dummies are included in the benchmark specification, the coefficient on experience is reduced by almost $50 \%$ while the one on age at entry is reduced by $30 \%$, suggesting that the previous results were partly capturing wage increases associated with upward movements within the rankings of the criminal organizations. This is reassuring in that the estimated equations do seem to capture relevant measures of productivity within drug-trafficking gangs.

\section{Careers in Drug-Trafficking Jobs}

\subsection{Age at Entry}

In this section, we use information on the age at which individuals joined the gang (henceforth, age at entry) to investigate which characteristics predict early entry. Early entry into crime is supposedly associated with a lower accumulation of human capital (that would be rewarded in the legal labor market) and consequently with higher chances of remaining in the criminal path. Chen et al (2005), for example, analyze the long-term criminal outcomes for youth that were apprehended by the police or brought before the Children's Court in Australia. They show that early initial contact with the justice system is correlated with a high probability of later involvement in crime. Therefore, age at entry is likely to be correlated with a more consistent long-term involvement with gang activity.

We estimate OLS regressions of age at entry on the following groups of variables: socioeconomic background (proxied by whether the gang-member had been raised by a single mother, 
the number of siblings he had, and whether the family owned the house in which he lived), home environment (proxied by occurrence of domestic violence while growing-up), schooling (a dummy for illiteracy), personality traits (whether individual was perceived by his family as unruly), and history of drug-use (whether he had started using drugs before age 13$).{ }^{14}$ We choose to use illiteracy as a measure of schooling because years of schooling may be endogenous to age at entry - i.e., joining the gang may lead members to drop out of school. Illiteracy status, on the other hand, should have been already determined by the time individuals decide to join the gang. Similarly, we choose the other family and individual related characteristics to reflect dimensions that, in principle, would be predetermined at the time of this decision.

The results are presented in Table 6. The two main correlates of age at entry are illiteracy and history of drug-use. Illiterate individuals typically joined the gang 1.3 years before literate individuals, suggesting that early school drop-outs join the gang at younger ages (there are very few - if any employment opportunities in the legal labor market for individuals younger than 14-15). Individuals who started using drugs before 13 typically entered the gang 1 year before other individuals. Of the other estimated coefficients, none is close to being statistically significant. These results suggest that troubled kids who have problems at school and start using drugs early on are at greater risk of being recruited at younger ages. Inciardi (1990), analyzing a population of adolescent offenders in Dade County (Miami), also highlights a strong relationship between drug use, entry into crime, and involvement with violence.

There are two limitations in this exercise. First, because we observe individuals years after initial entry, this sample is a selected sample of individuals who had not been killed and had not quit the drug gang between entry and the moment of the interview. Second, because the variables in the survey are measured after entry, they may be endogenous to age of entry. As mentioned before, to minimize the latter potential problem, we restricted the analysis to independent variables that would have been determined before age 13 and remained constant throughout the individual's lifetime.

\subsection{Occupational Progression}

Next, we consider which characteristics determine an individual's occupation within the drugtrafficking hierarchy. In order to conduct this analysis, we estimate a multinomial logit with outcomes corresponding to the four different occupational categories listed before: lookouts and local transporters; street-sellers and wrappers; soldiers; and managers. For ease of exposition, we call these occupational

\footnotetext{
${ }^{14}$ Qualitative and quantitative results are very similar if we estimated the model as an ordered logit with the independent variable indicating age brackets (less than 10, from 10 to 12, from 13 to 15, from 16 to 18, and above 18). We show the OLS results because they are easier to interpret.
} 
categories from now on, respectively, entry, mid-level, soldier, and manager. Given the evidence from the wage equations, we estimate two specifications. The first one includes demographic and family background variables, namely race, experience, age at entry, schooling, a dummy for being raised by a single mother, ownership of real estate, number of siblings, and a dummy for physical disability. The second specification includes also variables proxying for performance within the gang: participation in armed conflicts and physical punishment for breaking the gang's rules.

Table 7 presents the marginal effects from the multinomial logit estimation for the probability that the individual was employed in each of the 4 different occupational categories. As expected, individuals with more experience are more likely to be in the higher-ranking occupations. The main result in Table 7 is that there is a positive association between participation in armed confrontations and ranking: individuals who had participated in armed confrontations were less likely to be employed in lower level occupations and more likely to be soldiers and managers. Individuals with one additional previous conflict experience were roughly 3 percentage points less likely to be in entry and mid-level positions and 2 percentage points more likely to be managers. There are two possible interpretations of this result. One is that individuals who participate in armed confrontations, either to defend the gang's turf or to invade rivals' territories, are promoted for showing commitment to the gang's core activities and willingness to engage in risk. Another possible explanation is that a greater involvement with violent activities is one of the duties of higher ranking occupations. Interestingly, having being physically punished for failing to comply with the gang's rules is associated with a lower probability of advancing to higher occupations (although the coefficient is imprecisely estimated and thus not significant). Age at entry is positively associated with ranking, indicating that individuals who join the gang at older ages may skip the entry-level positions and already start in higher occupations. Members with a physical disability were less likely to be employed in entry level occupations - look-outs and transporters - because these occupations require mobility.

Overall, the results related to the determinants of occupation within the gang's hierarchy fall in line with the previous results from the wage equations. This is reassuring in that we seem to be identifying indeed dimensions that are deemed relevant for productivity within the gang.

\subsection{Exit}

In this section, we analyze the determinants of exit (temporary or permanent) from the gang using longitudinal data from monthly follow-up surveys that tracked the gang-members over a fourmonth period after the initial interview. Even though the data are noisy, they provide a unique opportunity to study what drives gang-members to voluntarily disassociate from drug-trafficking. We 
have data for only 189 gang-members out of the 225 that were initially interviewed and the attrition rate is high (in each wave, on average, 50 respondents could not be found; in addition, 19 were killed and 1 arrested during this period),

In the analysis, we estimate a conventional logistic hazard model (Allison, 1982, and Efron, 1988). The unit of observation is individual $i$ in wave $t$ if he was known to be at risk (so individuals who were not interviewed in wave $t$ - either because they were in prison, had been murdered, or could not be located - are not part of the sample). For simplicity, we assume that exiting the gang is an absorbing state, such that an individual who quit in wave $t$ is not at risk in subsequent waves. The dependent variable, $Y_{i, j}$, is 1 if individual $i$ exited the drug-gang in wave $t$ and 0 if individual $i$ was still drugtrafficking in wave $t$. We run logit regressions, including dummies for each wave.

We start from a specification including as independent variables demographic and family characteristics (race, experience, education, whether individual was raised by a single mother, whether the family owned the house where he lived, and number of siblings). Following, to capture the individual's attachment to the gang, we include a dummy indicating whether he had a legal job before joining the gang, and another dummy indicating whether he had previously quit the gang voluntarily. Finally, we include variables capturing his exposure to violence inside the gang (number of gun fights with police and rivals) and personality traits (a dummy indicating whether the individual was seen as unruly by his family). The main goal of this sequence of specification is to capture, in addition to standard demographic and family related variables, dimensions that would reveal the individual's connection with the gang and his history inside it.

The results shown in Table 8 suggest that gang-members with weaker attachment to the gang and better outside opportunities were more likely to quit. Members who reported in the baseline interview that they had exited the gang before were roughly 10 percentage points more likely to quit again. Gangmembers with more years of experience, who supposedly had developed stronger ties, were less likely to quit. Each year of experience reduces the probability of exit by 2 percentage points. Together, these results indicate that some members of the gang had a weaker attachment to it, working on and off for the gang. Members who had a legal job before joining the gang, and who supposedly could more easily find another job, were 4 percentage points more likely to quit (although the result is not statistically significant). Finally, members more exposed to risk - as proxied by the number of armed confrontations with rival gangs and with the police - were more likely to quit, with each participation in an armed confrontation being correlated with an increase of 1 percentage point in the probability of exiting. 
The results suggest that weaker initial attachment to the gang increases the probability of later exit. At the same time, individuals seem to be aware of the risks that they are exposed to when working for the gang: conditional on other observable characteristics, previous involvement with violence does increase the probability of later exit. In combination, these open up the possibility for better outside options for gang-members - maybe through targeted reintegration programs - to have potentially large effects on the involvement of youth with gang violence.

\subsection{Mortality after Two Years}

In Table 9, we examine which individual characteristics predict the likelihood of death within two years of the baseline interview. These data were collected either directly or indirectly, through relatives and friends. We estimate a linear probability model by OLS following the same sequence of specifications from Table 8 (marginal effects from a logit specification are almost identical).

The results show - perhaps not surprisingly - that members who were more involved with the violent activities of the gang at the time of the baseline interview, proxied by the number of armed confrontations, were more likely to die in the following two years. Each additional confrontation is associated with a 2 percentage-point increase in the probability of death. Consistent with this result, members who reported in the baseline interview that they had temporarily stopped working for the gang before were 8 percentage points less likely to die. The standard errors are, however, imprecisely estimated and the coefficient is not statistically different from zero.

The risk of death is also predicted by whether the individual was perceived as unruly by his family. Unruly individuals were 16 percentage points more likely to be dead at the end of the two-year period. This result is similar to that obtained by Chandler et al (2011). The authors analyzed data from Chicago public schools and found that children with disciplinary and behavioral problems had a higher risk of being shot within a given year. Blumstein et al (1986) also document a relationship between personality traits associated with lack of discipline and parental control and early involvement with violence. Extreme negative outcomes, therefore, seem to be associated to a great extent with recurrent involvement with violence and behavioral problems.

None of the other variables, including proxies for family background, predict mortality. The only exception is the coefficient on being raised by a single mother, which is large and marginally significant. If taken at face value, the point estimate implies that gang-members that had been raised by a single mother were 9 percentage points more likely to end up killed. 


\section{Concluding Remarks}

This paper uses a unique dataset of individuals employed in drug-trafficking gangs operating in favelas of Rio de Janeiro to draw an unprecedented picture of the criminal entry, career, and exit alternatives among gang-members. We explore a survey conducted by Observatório de Favelas, a Brazilian NGO, that collected detailed information on demographics, family background, and criminal activities for individuals involved with drug-trafficking gangs. We document that gang-members worked long hours and earned little more than other youth from the favelas working in the legal sector. Still, there were large risks associated with gang-membership: at the time of the first interview, more than two-thirds of the sample had participated in gun fights and, after two years, $20 \%$ were dead. The results also show that younger individuals, from lower socioeconomic background (black, illiterate, and from poorer families) and with no religious affiliation were more likely to be gang-members. Education was not rewarded within the gang, but experience, displays of bravery, and loyalty were. We find that kids who dropped out of school early on and who had early problems with drugs were more likely to join the gang also at earlier ages. Finally, we present evidence that gang-members with weaker attachment to the gang and better outside opportunities were more likely to quit the gang; those with more previous involvement with violence and personality traits associated with aggressiveness and lack of control, on the other hand, were more likely to die within two years. The provision of education and social support for troubled children may therefore constitute a good combination of policies to delay entry into crime and to reduce the probability of extreme negative outcomes for those who enter crime. Still, the results presented here should be taken only as a first step in the direction of understanding the determinants of youth involvement with criminal gangs. A main puzzle that remains is the motivation behind youth involvement with gang activities: monetary returns are relatively low and risks are extremely high. A departure from the more strict economic analysis of crime, focused simply on monetary returns, seems to be needed in order to advance the knowledge in the area. 


\section{References}

Allison, P.D. (1982). Discrete-time methods for the analysis of event histories. In: Leinhardt, S. (Ed.), Sociological Methodology. Josey-Bass, San Francisco, CA.

Blattman, Christopher and Jeannie Annan (2008). Child Combatants in Northern Uganda: Reintegration Myths and Realities. In: Robert Muggah (ed.). Security and Post-Conflict Reconstruction: Dealing with Fighters in the Aftermath of War, Routledge, 103-126.

Blattman, Christopher and Jeannie Annan (2010). The Consequences of Child Soldering. Review of Economics and Statistics, v92, n4, 882-898.

Blumstein, Alfred, Jacqueline Cohen, Jeffrey A. Roth, and Christy A. Visher (1986). Criminal Careers and "Career Criminals." National Academy Press, Washington DC, 489p.

Cerqueira, Daniel and Rodrigo R. Soares (2012). "The Welfare Cost of Homicides in Brazil: Accounting for Heterogeneity in the Willingness to Pay for Mortality Reductions." PUC-Rio Working Paper n600.

Chandler, Dana, Steven D. Levitt, and John A. List (2011). Predicting and Preventing Shootings among At-Risk Youth. American Economic Review Papers and Proceedings, 101(3), 288-92.

Chen, Shuling, Tania Matruglio, Don Weatherburn, and Jiuzhao Hua (2005). The Transition from Juvenile to Adult Criminal Careers. Crime and Justice Bulletin - Contemporary Issues in Crime and Justice, n86, 1-12.

Chioda, Laura, João Manoel De Mello, and Rodrigo Soares (2010). "Does Education Reduce Crime and Violence? Evidence from Bolsa Família and Extending the School Day in São Paulo.” Unpublished manuscript, PUC-Rio.

De La Rosa, Mario, Elizabeth Y. Lambert, and Bernard Gropper (1990). Drugs and Violence: Causes, Correlates, and Consequences. NIDA Research Monograph 103, US Department of Health and Public Services, Rockville, 293p.

Deming, David (2011). Better Schools, Less Crime? Quarterly Journal of Economics, forthcoming.

Dowdney, Luke (2003). Crianças do Tráfico: Um Estudo de Caso de Crianças em Violência Armada Organizada no Rio De Janeiro. Editora Sete Letras, Rio de Janeiro, 211p.

Efron, B. (1988). Logistic regression, survival analysis, and the Kaplan-Meier curve. Journal of the American Statistical Association 83, 414-425.

Gottfredson, Denise C. and David A. Soulé (2005). The Timing of Property Crime, Violent Crime, and Substance Use among Juveniles. Journal of Research in Crime and Delinquency, 42(110), 110-120.

Iniciardi, James A. (1990). The Crack-Violence Connection within a Population of Hard-Core Adolescent Offenders. In: Mario De La Rosa, Elizabeth Y. Lambert, and Bernard Gropper. Drugs and Violence: Causes, Correlates, and Consequences. NIDA Research Monograph 103, US Department of Health and Public Services, Rockville, 160-176.

Jacob, Brian A. and Lars Lefgren (2003). Are Idle Hands the Devil's Workshop? Incapacitation, Concentration, and Juvenile Crime. American Economic Review, 93(5), 1560-1577.

Lancaster, Tony and Guido Imbens (1996). Case-control Studies with Contaminated Controls. Journal of Econometrics, v71, n1-2, 145-16.

Lee, David S. amd Justin McCrary (2005). “Crime, Punishment, and Myopia.” NBER Working Paper 11491. 
Leland, Anne and Mari-Jana Oboroceanu (2010). "American War and Military Operations Casualties: Lists and Statistics." Congressional Research Service Report for Congress 7-5700, RL32492. Washington, DC.

Leeson, Peter T. (2007). An-arrg-chy: The Law and Economics of Pirate Organization. Journal of Political Economy, v115, n6, 1049-1094.

Levitt, Steven D. and Lance Lochner (2001). The Determinants of Juvenile Crime. In: Jonathan Gruber (ed). Risky Behavior among Youths: An Economic Analysis. University of Chicago Press, Chicago, 327-373.

Levitt, Steven D. and Sudhir Alladi Venkatesh (2000). An Economic Analysis of a Drug-Selling Gang's Finances. Quarterly Journal of Economics, v115, n3, 755-789.

Levitt, Steven D. and Sudhir Alladi Venkatesh (2001). Growing Up in the Projects: The Economic Lives of a Cohort of Men Who Came of Age in Chicago Public Housing. American Economic Review Papers and Proceedings, v91, n2, 79-84.

Lochner, Lance and Enrico Moretti (2004). The Effect of Education on Crime: Evidence from Prison Inmates, Arrests, and Self-Reports. American Economic Review, 94(1), 155-189.

Lochner, Lance (2010). "Education Policy and Crime.” NBER Working Paper 15894.

Luallen, Jeremy (2006). School's out. . . forever: A study of juvenile crime, at-risk youths and teacher strikes. Journal of Urban Economics, 59(1), 75-103.

Machin, Stephen, Olivier Marie, and Sunčica Vujić (2010). "The Crime Reducing Effect of Education." IZA Discussion Paper n5000.

Moore, Joan (1990). Gangs, Drugs, and Violence. In: Mario De La Rosa, Elizabeth Y. Lambert, and Bernard Gropper. Drugs and Violence: Causes, Correlates, and Consequences. NIDA Research Monograph 103, US Department of Health and Public Services, Rockville, 160-176.

NEPAD \& CLAVES (2000). "Estudo Global Sobre O Mercado Ilegal de Drogas no Rio de Janeiro." Unpublished Manuscript, UERJ / FIOCRUZ.

Neto, Octávio Cruz, Marcelo Rasga Moreira and Luiz Fernando Mazzei Sucena (2001). Nem Soldados Nem Inocentes. Rio de Janeiro, Editora Fiocruz, 200p.

Observatório de Favelas (2006). "Caminhada de Crianças, Adolescentes e Jovens na Rede do Tráfico de Drogas no Varejo do Rio de Janeiro, 2004-2006 - Sumário Executivo.” Unpublished Manuscript, Observatório de Favelas.

Paula, Liana and Renato Lima (2008). Violência e Juventude: O Sistema Brasileiro de Atendimento Socioeducativo. Segurança Pública, n4, 71-82.

Rubio, Mauricio (2007). De la Pandilla a la Mara: Pobreza, Educación, Mujeres y Violencia Juvenil. Publicaciones Universidad Externado de Colombia, 579p.

Silva, Jailson de Souza and André Urani (2002). Brazil, Children in Drug-trafficking: A Rapid Assessment. International Labour Organisation (IPEC), Geneva, 108p.

Snyder, Howard N. and Melissa Sickmund (1999). Juvenile Offenders and Victims: 1999 National Report. US Department of Justice Programs, Office of Juvenile Justice and Delinquency Prevention, Washington DC.

Soares, Rodrigo R. (2006). The Welfare Cost of Violence across Countries. Journal of Health Economics, 25(5), September 2006, 821-846. 
UNODC (2012). World Drug Report 2012. United Nations Office on Drugs and Crime, Vienna. 
Table 1: Characteristics of Drug Trafficking Jobs

\begin{tabular}{|c|c|c|c|c|c|}
\hline \multirow{2}{*}{ Monthly Earnings } & \multirow[b]{2}{*}{$\begin{array}{c}\text { All } \\
(100 \%) \\
\end{array}$} & \multicolumn{4}{|c|}{ Occupation in Drug Traffic Hierarchy } \\
\hline & & $\begin{array}{c}\text { Watchers and } \\
\text { Transporters } \\
(20.2 \%) \\
\end{array}$ & $\begin{array}{c}\text { Street-sellers } \\
\text { and Wrappers } \\
(42.6 \%)\end{array}$ & $\begin{array}{l}\text { Soldiers } \\
(24.8 \%)\end{array}$ & $\begin{array}{c}\text { Managers } \\
(12.4 \%)\end{array}$ \\
\hline Work Hours (per work day) & 10.8 & 10.8 & 10.9 & 10.5 & 11.4 \\
\hline Number of Days Off (per week) & 0.6 & 0.4 & 0.5 & 0.8 & 0.5 \\
\hline \multicolumn{6}{|l|}{ Works Armed? } \\
\hline Sporadically & $26 \%$ & $30 \%$ & $34 \%$ & $17 \%$ & $7 \%$ \\
\hline Everyday & $47 \%$ & $30 \%$ & $39 \%$ & $61 \%$ & $78 \%$ \\
\hline \multicolumn{6}{|l|}{ Apprehension and Police Extorsion } \\
\hline Ever in Juvenile Detention? & $29 \%$ & $23 \%$ & $29 \%$ & $28 \%$ & $41 \%$ \\
\hline Ever Arrested? & $53 \%$ & $45 \%$ & $49 \%$ & $54 \%$ & $70 \%$ \\
\hline Ever Gun Fight with Police? & $68 \%$ & $36 \%$ & $63 \%$ & $85 \%$ & $100 \%$ \\
\hline Ever Perpetrator of Physical Punishment? & $34 \%$ & $23 \%$ & $32 \%$ & $45 \%$ & $48 \%$ \\
\hline Ever Comitted Homicide? & $18 \%$ & $2 \%$ & $19 \%$ & $27 \%$ & $27 \%$ \\
\hline Ever Wounded in Combat? & $24 \%$ & $7 \%$ & $14 \%$ & $37 \%$ & $56 \%$ \\
\hline Ever Victim of Physical Punishment? & $22 \%$ & $27 \%$ & $27 \%$ & $20 \%$ & $11 \%$ \\
\hline Killed within 2 Years & $20 \%$ & $18 \%$ & $18 \%$ & $20 \%$ & $30 \%$ \\
\hline Observations & 225 & 44 & 93 & 54 & 27 \\
\hline
\end{tabular}

Note: The table reports summary statistics for the 225 young men interviewed in the Observatorio de Favelas survey. The first column shows statistics for the entire sample, while the last four columns report statistics by occupation. Following Dowdney (2003), we classify respondents into four occupation categories: (1) "Watchers" who observe the area to warn in case of police presence and "Transporters" who move small quantitities of drugs within a favela; (2) "Street-sellers" who sell directly to consumers and "Wrappers" who handle and wrap the durg before sale to consumers; (3) "Soldiers" who are responsible for local security and who play a major role in armed confrotations; and (4) "Managers" who may be responsible for the entire operation in a favela or be in charge of the market for one specific drug. There were 7 respondents who we did not categorize into any of the four occupation categories because their job assignments did not fall into any of the specified categories. 
Table 2: Characteristics of Gang-Members and Young Men Living in Favelas

\begin{tabular}{|c|c|c|}
\hline & $\begin{array}{c}\text { OF Survey } \\
\text { Men } \\
\end{array}$ & $\begin{array}{c}\text { Brazilian Census } \\
\text { Men 10-25 Living } \\
\text { in Rio's Favelas } \\
\end{array}$ \\
\hline Age & 16.7 & 17.5 \\
\hline \multicolumn{3}{|l|}{ Race } \\
\hline White & $29 \%$ & $38 \%$ \\
\hline Black & $27 \%$ & $14 \%$ \\
\hline Mixed-Race & $37 \%$ & $46 \%$ \\
\hline Other & $7 \%$ & $0 \%$ \\
\hline \multicolumn{3}{|l|}{ Religion } \\
\hline No Religion & $43 \%$ & $24 \%$ \\
\hline Catholic & $39 \%$ & $54 \%$ \\
\hline Evangelical & $16 \%$ & $19 \%$ \\
\hline Other & $2 \%$ & $2 \%$ \\
\hline \multicolumn{3}{|l|}{ Marital Status } \\
\hline Single & $91 \%$ & $96 \%$ \\
\hline Married & $9 \%$ & $4 \%$ \\
\hline Illiterate & $9 \%$ & $4 \%$ \\
\hline Currently Attends School? & $10 \%$ & $54 \%$ \\
\hline Years of Schooling & 5.4 & 5.5 \\
\hline \multicolumn{3}{|l|}{ Employment Status } \\
\hline Unemployed & - & $12 \%$ \\
\hline Employed & - & $40 \%$ \\
\hline Not in Labor Force & - & $48 \%$ \\
\hline Monthly Earnings & 316 & 256 \\
\hline Less than minimum wage & $8 \%$ & $21 \%$ \\
\hline Between 1 and 3 times the Minimum Wage & $68 \%$ & $67 \%$ \\
\hline Between 3 and 5 times the Minimum Wage & $19 \%$ & $9 \%$ \\
\hline More than 5 times the minimum wage & $4 \%$ & $2 \%$ \\
\hline Family Owns House & $73 \%$ & $83 \%$ \\
\hline Observations & 225 & 17,175 \\
\hline
\end{tabular}

Note: The table reports means, separately for young men employed in the drug traffic business interviewed in the Observatorio de Favelas survey (column 1) and young men ages 10-25 living in households located in favelas in the city of Rio that were interviewed in the 2000 Brazilian Census (column 2). 
Table 3: Participation in the Illegal Sector

Dependent Variable: Employed by Drug Traffic Business

\begin{tabular}{|c|c|c|c|c|}
\hline \multirow{3}{*}{ Black } & \multicolumn{4}{|c|}{ Fraction young men drug-trafficking $=5 \%$} \\
\hline & 0.44 & 0.42 & 0.43 & 0.33 \\
\hline & {$[0.096]^{* * *}$} & {$[0.083]^{* * *}$} & {$[0.081]^{* * *}$} & {$[0.070]^{* * *}$} \\
\hline \multirow[t]{2}{*}{ Age } & -0.02 & -0.02 & -0.03 & -0.03 \\
\hline & {$[0.004]^{* * *}$} & {$[0.003]^{* * *}$} & {$[0.004]^{* * *}$} & {$[0.004]^{* * *}$} \\
\hline \multirow[t]{2}{*}{ Illiterate } & & 0.46 & 0.41 & 0.39 \\
\hline & & {$[0.140]^{* * *}$} & {$[0.132]^{* * *}$} & {$[0.140]^{* * *}$} \\
\hline \multirow[t]{2}{*}{ Owns House } & & & -0.29 & -0.26 \\
\hline & & & {$[0.067]^{* * *}$} & {$[0.071]^{* * *}$} \\
\hline \multirow[t]{2}{*}{ No Religion } & & & & 0.38 \\
\hline & & & & {$[0.064]^{* * *}$} \\
\hline \multirow[t]{2}{*}{$h$} & 0.010 & 0.013 & 0.013 & 0.013 \\
\hline & {$[0.001] * * *$} & {$[0.001] * * *$} & {$[0.001]^{* * *}$} & {$[0.001]^{* * *}$} \\
\hline \multirow[t]{3}{*}{ Constant } & -1.73 & -1.76 & -1.53 & -1.64 \\
\hline & {$[0.025]^{* * *}$} & {$[0.023]^{* * *}$} & {$[0.057]^{* * *}$} & {$[0.069]^{* * *}$} \\
\hline & Fraction & young men $\mathrm{d}$ & rug-trafficking & $y=5 \%$ \\
\hline \multirow[t]{2}{*}{ Black } & 0.06 & 0.05 & 0.05 & 0.04 \\
\hline & {$[0.014]^{* * *}$} & {$[0.012]^{* * *}$} & {$[0.012]^{* * *}$} & {$[0.010]^{* * *}$} \\
\hline \multirow[t]{2}{*}{ Age } & -0.002 & -0.002 & -0.003 & -0.003 \\
\hline & {$[0.0004]^{* * *}$} & {$[0.0003]^{* * *}$} & {$[0.0003]^{* * *}$} & {$[0.0003]^{* * *}$} \\
\hline \multirow[t]{2}{*}{ Illiterate } & & 0.06 & 0.05 & 0.05 \\
\hline & & {$[0.025] * *$} & {$[0.022]^{* *}$} & {$[0.022]^{* *}$} \\
\hline \multirow[t]{2}{*}{ Owns House } & & & -0.03 & -0.03 \\
\hline & & & {$[0.009]^{* * *}$} & {$[0.009]^{* * *}$} \\
\hline \multirow[t]{2}{*}{ No Religion } & & & & 0.04 \\
\hline & & & & {$[0.008]^{* * *}$} \\
\hline
\end{tabular}

Panel A: Participation Equation (GMM)

\begin{tabular}{cccc}
\multicolumn{4}{c}{ Fraction young men drug-trafficking $=$} \\
\hline 0.54 & 0.51 & 0.51 & 0.38 \\
{$[0.096]^{* * *}$} & {$[0.102]^{* * *}$} & {$[0.099]^{* * *}$} & {$[0.087]^{* * *}$} \\
-0.03 & -0.03 & -0.03 & -0.03 \\
{$[0.005]^{* * *}$} & {$[0.004]^{* * *}$} & {$[0.005]^{* * *}$} & {$[0.005]^{* * *}$} \\
& 0.56 & 0.50 & 0.46 \\
& {$[0.176]^{* * *}$} & {$[0.164]^{* * *}$} & {$[0.174]^{* * *}$} \\
& & -0.34 & -0.29 \\
& & {$[0.082]^{* * *}$} & {$[0.086]^{* * *}$} \\
0.010 & 0.013 & 0.013 & 0.45 \\
{$[0.0011]^{* * *}$} & {$[0.001]^{* * *}$} & {$[0.001]^{* * *}$} & {$[0.001]^{* * *}$} \\
-1.39 & -1.42 & -1.14 & -1.28 \\
{$[0.024]^{* * *}$} & {$[0.027]^{* * *}$} & {$[0.071]^{* * *}$} & {$[0.084]^{* * *}$}
\end{tabular}

\begin{tabular}{|c|c|c|c|}
\hline \multicolumn{4}{|c|}{ Fraction young men drug-trafficking $=15 \%$} \\
\hline 0.63 & 0.59 & 0.58 & 0.43 \\
\hline$[0.129] * * *$ & {$[0.120] * * *$} & {$[0.116] * * *$} & {$[0.102] * * *$} \\
\hline-0.03 & -0.03 & -0.04 & -0.04 \\
\hline$[0.006] * * *$ & {$[0.005] * * *$} & {$[0.006] * * *$} & {$[0.006] * * *$} \\
\hline & 0.68 & 0.57 & 0.51 \\
\hline & {$[0.214]^{* * *}$} & {$[0.194]^{* * * *}$} & {$[0.206]^{* *}$} \\
\hline & & -0.38 & -0.32 \\
\hline & & {$[0.096]^{* * * *}$} & {$[0.101] * * *$} \\
\hline & & & 0.50 \\
\hline & & & {$[0.090] * * *$} \\
\hline 0.011 & 0.013 & 0.013 & 0.013 \\
\hline$[0.001]^{* * *}$ & {$[0.001] * * *$} & {$[0.001]^{* * *}$} & {$[0.001] * * *$} \\
\hline-1.16 & -1.19 & -0.88 & -1.03 \\
\hline$[0.030]^{* * *}$ & {$[0.030] * * *$} & {$[0.084] * * *$} & {$[0.096] * * *$} \\
\hline
\end{tabular}

\section{Panel B: Marginal Effects}

\begin{tabular}{|c|c|c|c|}
\hline \multicolumn{4}{|c|}{ Fraction young men drug-trafficking $=10 \%$} \\
\hline 0.11 & 0.11 & 0.11 & 0.07 \\
\hline$[0.024] * * *$ & {$[0.025]^{* * *}$} & {$[0.024] * * *$} & {$[0.020]^{* * *}$} \\
\hline-0.004 & -0.005 & -0.006 & -0.005 \\
\hline
\end{tabular}

Fraction young men drug-trafficking $=15 \%$

\begin{tabular}{cccc}
\hline 0.17 & 0.16 & 0.16 & 0.11 \\
{$[0.041]^{* * *}$} & {$[0.037]^{* * *}$} & {$[0.036]^{* * * *}$} & {$[0.030]^{* * *}$} \\
-0.007 & -0.007 & -0.009 & -0.009
\end{tabular}

$[0.0008]^{* * *}[0.0007]^{* * *}[0.0007]^{* * *}[0.0007]^{* * *}$

$$
\begin{array}{ccc}
0.13 & 0.11 & 0.10 \\
{[0.050]^{* *}} & {[0.044]^{* *}} & {[0.045]^{* *}} \\
& -0.06 & -0.05 \\
& {[0.017]^{* * *}} & {[0.018]^{* * *}} \\
& & 0.08 \\
& & {[0.016]^{* * *}}
\end{array}
$$

$[0.0013]^{* * *}\left[\begin{array}{cccc}-0.0011 & {[* * *} & {[0.0012}\end{array}\right]^{* * *}[0.0012]^{* * *}$

$$
\begin{array}{ccc}
0.20 & 0.16 & 0.14 \\
{[0.076]^{* * *}} & {[0.066]^{* *}} & {[0.067]^{* *}} \\
& -0.09 & -0.08 \\
& {[0.027]^{* * *}} & {[0.027]^{* * *}} \\
& & 0.13 \\
& & {[0.025]^{* * *}}
\end{array}
$$

$\begin{array}{lrrrr}\text { Observations } & 17,399 & 17,399 & 17,399 & 17,399\end{array}$

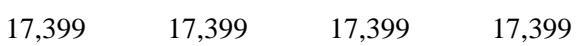

$17,399 \quad 17,399 \quad 17,399 \quad 17,399$

Note: The table reports results of the Maximum Likelihood estimation of participation in the illegal sector using the estimator proposed by Lancaster and Imbens (1996). Panel A reports the results from the MLE estimation. Panel B reports the marginal effects. The three different set of results correspond to different assumptions about which fraction of young men 10-25 living in favelas were employed by the drug business (q). The sample is formed by young men 10-25 living in favelas of Rio surveyed by the 2000 Brazilian Census and 225 young men employed by the drug traffic business interviewed in the OF survey. Robust standard errors in brackets. 
Table 4: Wages in the Illegal Sector

\begin{tabular}{|c|c|c|c|c|c|c|}
\hline \multirow{4}{*}{ Black } & \multicolumn{6}{|c|}{ Dependent Variable: Log Wages (OLS) } \\
\hline & \multicolumn{3}{|c|}{ No Correction for Self-Selection } & \multicolumn{3}{|c|}{ Fraction young men drug-trafficking $=5 \%$} \\
\hline & 0.03 & 0.03 & 0.03 & 0.01 & 0.10 & 0.09 \\
\hline & [0.092] & [0.092] & [0.092] & [0.109] & [0.115] & [0.124] \\
\hline \multirow[t]{2}{*}{ Age } & 0.10 & 0.10 & 0.10 & 0.10 & 0.09 & 0.09 \\
\hline & {$[0.020]^{* * *}$} & {$[0.019]^{* * *}$} & {$[0.019]^{* * *}$} & {$[0.021]^{* * *}$} & {$[0.021]^{* * *}$} & {$[0.022]^{* * *}$} \\
\hline \multirow[t]{2}{*}{ Illiterate } & & 0.25 & 0.26 & & 0.32 & 0.31 \\
\hline & & {$[0.109]^{* *}$} & {$[0.113]^{* *}$} & & {$[0.138]^{* *}$} & {$[0.140]^{* *}$} \\
\hline \multirow[t]{2}{*}{ Owns House in which Lives } & & & 0.05 & & & 0.01 \\
\hline & & & [0.092] & & & [0.109] \\
\hline \multirow[t]{2}{*}{ Mills Ratio } & & & & -0.05 & 0.18 & 0.16 \\
\hline & & & & [0.174] & {$[0.212]$} & [0.251] \\
\hline \multirow[t]{2}{*}{ Constant } & 5.63 & 5.61 & 5.57 & 5.75 & 5.23 & 5.25 \\
\hline & {$[0.045]^{* * *}$} & {$[0.047]^{* * *}$} & {$[0.085]^{* * *}$} & {$[0.362]^{* * *}$} & {$[0.450]^{* * *}$} & {$[0.493]^{* * *}$} \\
\hline \multirow[t]{2}{*}{ Observations } & 221 & 221 & 221 & 221 & 221 & 221 \\
\hline & \multicolumn{3}{|c|}{ Fraction young men drug-trafficking $=10 \%$} & \multicolumn{3}{|c|}{ Fraction young men drug-trafficking $=15 \%$} \\
\hline \multirow[t]{2}{*}{ Black } & 0.01 & 0.10 & 0.09 & 0.01 & 0.10 & 0.09 \\
\hline & [0.109] & [0.115] & [0.123] & [0.109] & [0.115] & [0.123] \\
\hline \multirow[t]{2}{*}{ Age } & 0.10 & 0.09 & 0.09 & 0.10 & 0.09 & 0.09 \\
\hline & {$[0.021]^{* * *}$} & {$[0.021]^{* * *}$} & {$[0.023]^{* * *}$} & {$[0.021]^{* * *}$} & {$[0.022]^{* * *}$} & {$[0.023]^{* * *}$} \\
\hline \multirow[t]{2}{*}{ Illiterate } & & 0.32 & 0.32 & & 0.32 & 0.32 \\
\hline & & {$[0.138]^{* *}$} & {$[0.140]^{* *}$} & & {$[0.137]^{* *}$} & {$[0.139]^{* *}$} \\
\hline \multirow[t]{2}{*}{ Owns House in which Lives } & & & 0.01 & & & 0.01 \\
\hline & & & [0.108] & & & [0.108] \\
\hline \multicolumn{7}{|l|}{ No Religion } \\
\hline \multirow[t]{2}{*}{ Mills Ratio } & -0.05 & 0.16 & 0.15 & -0.04 & 0.16 & 0.14 \\
\hline & [0.157] & [0.192] & [0.225] & [0.150] & [0.179] & [0.209] \\
\hline \multirow[t]{2}{*}{ Constant } & 5.72 & 5.31 & 5.33 & 5.70 & 5.35 & 5.36 \\
\hline & {$[0.279]^{* * *}$} & {$[0.350]^{* * *}$} & {$[0.373]^{* * *}$} & {$[0.233]^{* * *}$} & {$[0.292]^{* * *}$} & {$[0.306]^{* * *}$} \\
\hline Observations & 221 & 221 & 221 & 221 & 221 & 221 \\
\hline
\end{tabular}

Note: The table reports results from OLS regressions in which the dependent variable is log of drug-trafficking wages. The first set of results do not control for selection. All the other results control for the Inverse Mills' Ratio implied by the most complete specification in Table 3. The

Mills' Ratio depends on the assumption about which fraction of young men were employed by the drug traffic business (q), which we assume to be either $5 \%, 10 \%$ or $15 \%$. 
Table 5: Wages in the Illegal Sector

\begin{tabular}{|c|c|c|c|c|c|c|c|}
\hline & \multicolumn{7}{|c|}{ Dependent Variable: Log Wages (OLS) } \\
\hline & $(1)$ & $(2)$ & $(3)$ & (4) & $(5)$ & (6) & (7) \\
\hline \multirow{2}{*}{ Black } & -0.02 & -0.02 & -0.04 & -0.02 & -0.05 & -0.04 & -0.07 \\
\hline & {$[0.096]$} & {$[0.095]$} & {$[0.092]$} & {$[0.096]$} & {$[0.091]$} & {$[0.092]$} & {$[0.090]$} \\
\hline \multirow[t]{2}{*}{ Experience } & 0.10 & 0.10 & 0.08 & 0.10 & 0.09 & 0.05 & 0.06 \\
\hline & {$[0.027]^{* * *}$} & {$[0.027] * * *$} & {$[0.026]^{* * *}$} & {$[0.027]^{* * *}$} & {$[0.025]^{* * *}$} & {$[0.023]^{* *}$} & {$[0.023]^{* *}$} \\
\hline \multirow[t]{2}{*}{ Age at Entry } & 0.09 & 0.09 & 0.09 & 0.10 & 0.09 & 0.07 & 0.07 \\
\hline & {$[0.028]^{* * *}$} & {$[0.028] * * *$} & {$[0.027]^{* * *}$} & {$[0.028]^{* * *}$} & {$[0.026]^{* * *}$} & {$[0.025]^{* *}$} & {$[0.024]^{* * *}$} \\
\hline \multirow[t]{2}{*}{ Education } & 0.00 & 0.00 & 0.00 & -0.01 & -0.01 & -0.01 & -0.01 \\
\hline & {$[0.020]$} & {$[0.020]$} & {$[0.019]$} & {$[0.020]$} & {$[0.019]$} & {$[0.019]$} & {$[0.018]$} \\
\hline \multirow[t]{2}{*}{ Single Mother } & 0.17 & 0.15 & 0.15 & 0.17 & 0.13 & 0.12 & 0.11 \\
\hline & {$[0.086]^{*}$} & {$[0.086]^{*}$} & {$[0.082]^{*}$} & {$[0.085]^{* *}$} & {$[0.082]$} & {$[0.082]$} & {$[0.080]$} \\
\hline \multirow[t]{2}{*}{ Owns House in which Lives } & 0.03 & 0.03 & 0.04 & 0.02 & 0.05 & -0.03 & -0.02 \\
\hline & {$[0.095]$} & {$[0.095]$} & {$[0.092]$} & {$[0.095]$} & {$[0.092]$} & {$[0.089]$} & {$[0.086]$} \\
\hline \multirow[t]{2}{*}{ Number of Siblings } & -0.01 & -0.01 & -0.02 & -0.01 & -0.02 & -0.01 & -0.02 \\
\hline & {$[0.025]$} & {$[0.025]$} & {$[0.025]$} & {$[0.025]$} & {$[0.024]$} & {$[0.023]$} & {$[0.023]$} \\
\hline \multirow[t]{2}{*}{ Physical Disability } & & -0.23 & & & -0.37 & & -0.22 \\
\hline & & [0.181] & & & {$[0.183]^{* *}$} & & {$[0.142]$} \\
\hline \multirow[t]{2}{*}{ \# Gun Fights } & & & 0.05 & & 0.05 & & 0.04 \\
\hline & & & {$[0.011]^{* * *}$} & & {$[0.010]^{* * *}$} & & {$[0.011]^{* * *}$} \\
\hline \multirow[t]{2}{*}{ Ever Victim of Physical Punishment? } & & & & -0.18 & -0.18 & & -0.17 \\
\hline & & & & {$[0.099]^{*}$} & {$[0.094]^{*}$} & & {$[0.093]^{*}$} \\
\hline \multicolumn{8}{|l|}{ Occupation } \\
\hline \multirow[t]{2}{*}{ Mid } & & & & & & 0.21 & 0.13 \\
\hline & & & & & & {$[0.112]^{*}$} & [0.114] \\
\hline \multirow[t]{2}{*}{ Soldier } & & & & & & 0.24 & 0.07 \\
\hline & & & & & & {$[0.111]^{* *}$} & [0.116] \\
\hline \multirow[t]{2}{*}{ Manager } & & & & & & 0.63 & 0.35 \\
\hline & & & & & & {$[0.126]^{* * *}$} & {$[0.149]^{* *}$} \\
\hline \multirow[t]{2}{*}{ Constant } & 3.96 & 3.96 & 3.94 & 3.99 & 3.95 & 4.35 & 4.29 \\
\hline & {$[0.420]^{* * *}$} & {$[0.417]^{* * *}$} & {$[0.398]^{* * *}$} & {$[0.420]^{* * *}$} & {$[0.386]^{* * *}$} & {$[0.380]^{* * *}$} & {$[0.360]^{* * *}$} \\
\hline Observations & 220 & 220 & 220 & 219 & 219 & 212 & 211 \\
\hline
\end{tabular}

Note: The table reports results from OLS regressions in which the dependent variable is the log of drug-trafficking wages. Robust standard errors between brackets. 
Table 6: Age at Entry

\begin{tabular}{|c|c|c|c|c|c|c|}
\hline & \multicolumn{6}{|c|}{ "Dependent Variable: Age at Entry (OLS) } \\
\hline & $(1)$ & $(2)$ & (3) & $(4)$ & $(5)$ & $(6)$ \\
\hline \multirow{2}{*}{ Single Mother } & 0.32 & & & & & 0.30 \\
\hline & [0.249] & & & & & [0.265] \\
\hline \multirow[t]{2}{*}{ Owns House in which Lives } & 0.17 & & & & & 0.01 \\
\hline & [0.317] & & & & & {$[0.316]$} \\
\hline \multirow[t]{2}{*}{ Number of Siblings } & -0.13 & & & & & -0.05 \\
\hline & {$[0.086]$} & & & & & [0.096] \\
\hline \multirow[t]{2}{*}{ Illiterate } & & -1.46 & & & & -1.26 \\
\hline & & {$[0.604]^{* *}$} & & & & {$[0.615]^{* *}$} \\
\hline \multirow[t]{2}{*}{ Started Using Drugs Before 13} & & & -1.09 & & & -1.11 \\
\hline & & & {$[0.305]^{* *}$} & & & {$[0.303]^{* *}$} \\
\hline \multirow[t]{2}{*}{ Domestic Violence } & & & & -0.04 & & 0.04 \\
\hline & & & & [0.314] & & {$[0.307]$} \\
\hline \multirow[t]{2}{*}{ Unruly } & & & & & -0.01 & 0.09 \\
\hline & & & & & [0.300] & [0.312] \\
\hline \multirow[t]{2}{*}{ Constant } & 14.94 & 14.99 & 15.12 & 14.88 & 14.83 & 15.32 \\
\hline & {$[0.363]^{* * *}$} & {$[0.121]^{* * *}$} & {$[0.135]^{* * *}$} & {$[0.160]^{* * *}$} & {$[0.145]^{* * *}$} & {$[0.400]^{* * *}$} \\
\hline Observations & 224 & 223 & 224 & 204 & 224 & 203 \\
\hline
\end{tabular}

Note: The table reports results from OLS regressions in which the dependent variable is age at which individual started working for the drug-traffic business. Age at entry was reported in brackets. We converted the answers into scalars by choosing the mid-point in each bracket, and 19 for the upper bracket (above 18 years old). Robust standard errors are reported between brackets. 
Table 7. Occupation in the Drug Traffic Hierarchy

\begin{tabular}{|c|c|c|c|c|c|c|c|c|}
\hline & \multicolumn{8}{|c|}{ "Dependent Variable: Occupation (Multinomial Logit - Marginal Effects) } \\
\hline & $\begin{array}{c}\text { Entry } \\
(1)\end{array}$ & $\begin{array}{l}\text { Mid } \\
(2)\end{array}$ & $\begin{array}{c}\text { Soldier } \\
\text { (3) }\end{array}$ & $\begin{array}{c}\text { Manager } \\
(4)\end{array}$ & $\begin{array}{c}\text { Entry } \\
(5)\end{array}$ & $\begin{array}{l}\text { Mid } \\
(6)\end{array}$ & $\begin{array}{c}\text { Soldier } \\
(7)\end{array}$ & $\begin{array}{c}\text { Manager } \\
(8)\end{array}$ \\
\hline \multirow[t]{2}{*}{ Black } & 0.00 & 0.05 & -0.04 & 0.00 & 0.01 & 0.09 & -0.08 & -0.02 \\
\hline & [0.038] & {$[0.080]$} & {$[0.071]$} & {$[0.055]$} & {$[0.028]$} & [0.084] & {$[0.080]$} & [0.019] \\
\hline \multirow[t]{2}{*}{ Experience } & -0.03 & 0.00 & -0.01 & 0.04 & -0.01 & 0.02 & -0.02 & 0.01 \\
\hline & {$[0.012]^{* *}$} & {$[0.027]$} & [0.029] & {$[0.015]^{* *}$} & [0.009] & {$[0.030]$} & {$[0.031]$} & {$[0.005]^{* *}$} \\
\hline \multirow[t]{2}{*}{ Age at Entry } & -0.02 & -0.02 & 0.01 & 0.03 & -0.01 & -0.02 & 0.01 & 0.02 \\
\hline & {$[0.012]$} & {$[0.026]$} & {$[0.025]$} & {$[0.016]^{* *}$} & [0.009] & [0.027] & {$[0.027]$} & {$[0.008]^{* *}$} \\
\hline \multirow[t]{2}{*}{ Education } & -0.01 & 0.01 & 0.00 & 0.00 & -0.01 & 0.01 & 0.00 & -0.01 \\
\hline & [0.009] & [0.019] & {$[0.018]$} & {$[0.013]$} & [0.007] & {$[0.020]$} & [0.019] & [0.005] \\
\hline \multirow[t]{2}{*}{ Single Mother } & -0.06 & 0.03 & 0.00 & 0.02 & -0.04 & 0.03 & 0.00 & 0.01 \\
\hline & {$[0.034]^{*}$} & {$[0.074]$} & {$[0.066]$} & {$[0.051]$} & {$[0.025]$} & {$[0.079]$} & {$[0.074]$} & [0.021] \\
\hline \multirow[t]{2}{*}{ Owns House in which Lives } & 0.01 & -0.05 & 0.03 & 0.02 & 0.01 & -0.06 & 0.04 & 0.01 \\
\hline & {$[0.036]$} & {$[0.081]$} & {$[0.075]$} & [0.052] & [0.027] & [0.087] & {$[0.085]$} & [0.018] \\
\hline \multirow{2}{*}{ Number of Siblings } & -0.01 & 0.00 & 0.01 & -0.01 & 0.00 & 0.00 & 0.00 & 0.00 \\
\hline & {$[0.011]$} & {$[0.024]$} & {$[0.022]$} & [0.016] & [0.008] & {$[0.026]$} & {$[0.025]$} & [0.005] \\
\hline \multirow[t]{2}{*}{ Physical Disability } & -0.20 & 0.06 & -0.08 & 0.21 & -0.13 & 0.15 & -0.10 & 0.08 \\
\hline & {$[0.030]^{* * *}$} & {$[0.162]$} & {$[0.124]$} & [0.142] & {$[0.036]^{* * *}$} & {$[0.150]$} & {$[0.138]$} & [0.055] \\
\hline \multirow[t]{2}{*}{ \# Gun Fights } & & & & & -0.02 & -0.03 & 0.03 & 0.02 \\
\hline & & & & & \multicolumn{4}{|c|}{$[0.004]^{* * *}[0.012] * *[0.011] * * *[0.006]^{* * *}$} \\
\hline \multirow[t]{2}{*}{ Ever Victim of Physical Punishment? } & & & & & 0.03 & 0.08 & -0.08 & -0.03 \\
\hline & & & & & [0.032] & [0.087] & {$[0.082]$} & [0.020] \\
\hline Observations & 213 & 213 & 213 & 213 & 212 & 212 & 212 & 212 \\
\hline
\end{tabular}

Note : Robust standard errors between brackets. The table presents marginal effects from a multinomial logit, where the dependent variable is occupation in the drug traffic hierarchy. The occupation categories are: (1) entry-level (watchers and transporters); (2) mid-level (street-sellers and wrappers); (3) soldiers; and (4) managers. 


\section{Table 8: Quit}

\begin{tabular}{|c|c|c|c|c|c|}
\hline & \multicolumn{5}{|c|}{ Dependent Variable: Quit (Logistic Hazard Model - Marginal Effects) } \\
\hline & $(1)$ & $(2)$ & $(3)$ & $(4)$ & $(5)$ \\
\hline \multirow[t]{2}{*}{ Black } & 0.07 & 0.05 & 0.06 & 0.07 & 0.05 \\
\hline & {$[0.038]^{*}$} & [0.034] & {$[0.037]^{*}$} & {$[0.038]^{*}$} & {$[0.034]$} \\
\hline \multirow[t]{2}{*}{ Experience } & -0.02 & -0.02 & -0.02 & -0.02 & -0.02 \\
\hline & {$[0.008]^{* *}$} & {$[0.008]^{* *}$} & {$[0.008]^{* * *}$} & {$[0.009]^{* *}$} & {$[0.008]^{* *}$} \\
\hline \multirow[t]{2}{*}{ Education } & -0.01 & -0.01 & -0.01 & -0.01 & -0.01 \\
\hline & {$[0.006]$} & {$[0.006]$} & {$[0.006]$} & {$[0.006]$} & {$[0.006]$} \\
\hline \multirow[t]{2}{*}{ Single Mother } & -0.02 & -0.04 & -0.02 & -0.02 & -0.03 \\
\hline & {$[0.029]$} & {$[0.026]$} & {$[0.028]$} & {$[0.030]$} & {$[0.026]$} \\
\hline \multirow[t]{2}{*}{ Owns House in which Lives } & 0.03 & 0.03 & 0.02 & 0.03 & 0.03 \\
\hline & {$[0.032]$} & [0.029] & {$[0.033]$} & {$[0.033]$} & {$[0.029]$} \\
\hline \multirow[t]{2}{*}{ Number of Siblings } & 0.01 & 0.00 & 0.01 & 0.01 & 0.00 \\
\hline & {$[0.008]$} & {$[0.008]$} & {$[0.008]$} & [0.009] & {$[0.008]$} \\
\hline \multirow[t]{2}{*}{ Have Had Other Job } & & 0.04 & & & 0.04 \\
\hline & & {$[0.030]$} & & & {$[0.029]$} \\
\hline \multirow[t]{2}{*}{ Have (Temporarily) Quit Before } & & 0.10 & & & 0.09 \\
\hline & & {$[0.036]^{* * *}$} & & & {$[0.035]^{* * *}$} \\
\hline \multirow[t]{2}{*}{ \# Gun Fights } & & & 0.01 & & 0.01 \\
\hline & & & {$[0.004]^{*}$} & & {$[0.003]^{*}$} \\
\hline \multirow[t]{2}{*}{ Unruly } & & & & 0.04 & 0.04 \\
\hline & & & & {$[0.045]$} & [0.044] \\
\hline Observations & 349 & 348 & 349 & 349 & 348 \\
\hline
\end{tabular}

Note : Robust standard errors between brackets. The table presents marginal effects from a logistic hazard model. The unit of observation is individual $i$ in wave $t$ if he was known to be at risk (so individuals who were not interviewed in wave $\mathrm{t}$ - either because they were in prison, had been murdered, or could not be located - are not part of the sample). We assume that exiting the gang is an absorbing state, such that an individual who quit in wave $t$ is not at risk in subsequent waves. The dependent variable, $\mathrm{Y}_{-} \mathrm{i}, \mathrm{j}$ is 1 if individual $\mathrm{i}$ exited the drug-gang in wave $\mathrm{t}$ and 0 if individual $\mathrm{i}$ was still drug-trafficking in wave t. We run logit regressions, including dummies for each wave. 
Table 9: Killed Within 2 Years

\begin{tabular}{|c|c|c|c|c|c|}
\hline & & $\overline{\overline{\text { Dependent }}}$ & Variable: $\mathrm{k}$ & illed (OLS & \\
\hline & (1) & (2) & (3) & (4) & (5) \\
\hline Black & -0.03 & -0.03 & -0.04 & -0.03 & -0.04 \\
\hline & [0.059] & [0.059] & {$[0.060]$} & {$[0.058]$} & {$[0.058]$} \\
\hline Experience & 0.01 & 0.02 & 0.01 & 0.02 & 0.02 \\
\hline & {$[0.017]$} & [0.017] & [0.017] & [0.017] & [0.017] \\
\hline Education & -0.02 & -0.02 & -0.02 & -0.01 & -0.02 \\
\hline & [0.013] & {$[0.013]$} & {$[0.012]$} & {$[0.013]$} & {$[0.012]$} \\
\hline Single Mother & 0.09 & 0.09 & 0.08 & 0.10 & 0.09 \\
\hline & [0.058] & {$[0.058]$} & [0.058] & {$[0.057]^{*}$} & [0.057] \\
\hline Owns House in which Lives & 0.00 & 0.00 & 0.01 & 0.00 & 0.00 \\
\hline & [0.064] & [0.066] & [0.064] & {$[0.065]$} & [0.066] \\
\hline Number of Siblings & 0.01 & 0.02 & 0.01 & 0.01 & 0.02 \\
\hline & [0.018] & [0.019] & [0.018] & {$[0.017]$} & [0.018] \\
\hline Have Had Other Job & & 0.02 & & & 0.01 \\
\hline & & {$[0.056]$} & & & {$[0.054]$} \\
\hline Have (Temporarily) Quit Before & & -0.08 & & & -0.09 \\
\hline & & [0.058] & & & [0.058] \\
\hline \# Gun Fights & & & 0.02 & & 0.02 \\
\hline & & & {$[0.008]^{* *}$} & & {$[0.008]^{* *}$} \\
\hline Unruly & & & & 0.16 & 0.17 \\
\hline & & & & {$[0.075]^{* *}$} & {$[0.073] * *$} \\
\hline Constant & 0.19 & 0.20 & 0.15 & 0.14 & 0.11 \\
\hline & {$[0.091]^{* *}$} & {$[0.096]^{* *}$} & {$[0.091]^{*}$} & [0.096] & {$[0.100]$} \\
\hline Observations & 224 & 223 & 224 & 224 & 223 \\
\hline
\end{tabular}

Note : Robust standard errors between brackets. The table presents results from an OLS regression in which the dependent variable is 1 if gang-member was dead two years after baseline interview and 0 otherwise. 


\section{Appendix Table A1: Family Background}

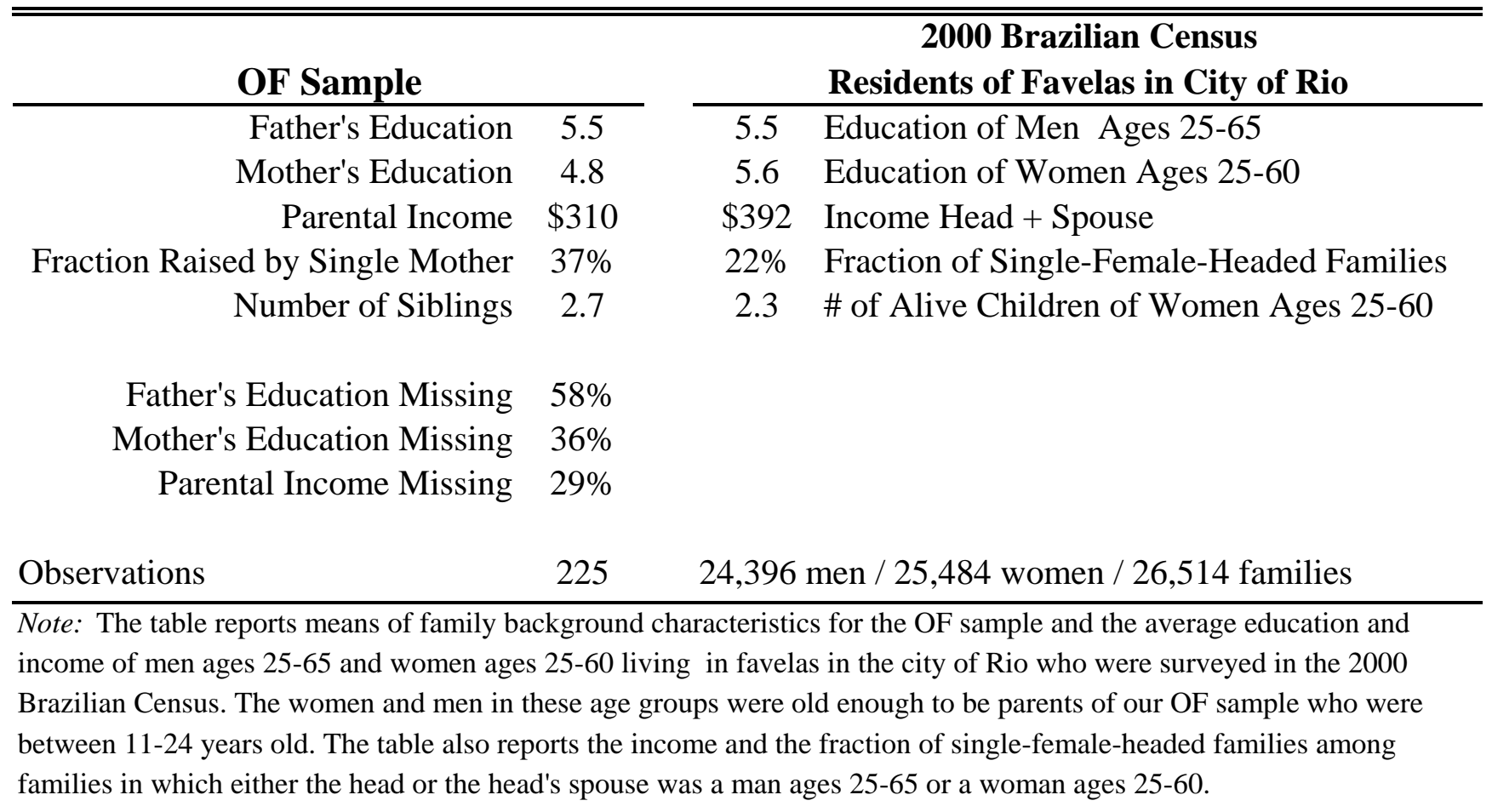

